\title{
Steel rod impalement injuries involving the spine: A case report and literature review
}

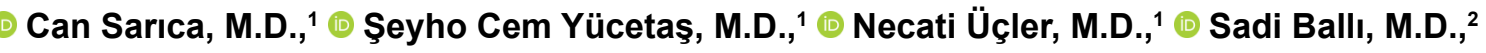

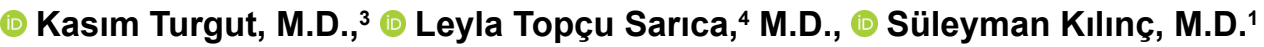

\author{
1'Department of Neurosurgery, Adıyaman University Faculty of Medicine, Adıyaman-Turkey \\ 2Department of General Surgery, Adıyaman University Faculty of Medicine, Adıyaman-Turkey \\ ${ }^{3}$ Department of Emergency Medicine, Adıyaman University Faculty of Medicine, Adıyaman-Turkey \\ ${ }^{4}$ Department of Anesthesiology and Reanimation, Adıyaman University Faculty of Medicine, Adıyaman-Turkey
}

\begin{abstract}
Steel rod impalements, mostly experienced by construction workers due to falls from heights, are known entities, but only some individuals unfortunately suffer spinal cord injury. The management of the spine involved injuries is challenging due to the lack of guidelines, various clinical presentations resulting from different trajectories, and high risk of infection. We report a case of steel rod impalement involving the spinal canal and review the literature to enhance the management strategies and to identify the risk factors for possible complications, particularly infection.A 37-year-old male construction worker presented to our emergency department due to falling onto a concrete reinforcing steel rod that penetrated through his perineum to the L4 vertebra. Examination revealed paralysis and sensory loss of the left foot. The rod was removed in the operating room (closed removal) under general anesthesia, followed by laparotomy. Rectal laceration was primarily repaired, and colostomy was performed. In a separate session, laminectomy was performed.At 3 months post-discharge, the patient was ambulatory with armrest based on the same motor examination performed on presentation This case is a good example of careful preoperative planning, multidisciplinary involvement, and appropriately sequenced interventions resulting in an acceptable outcome for an injury with high morbidity and mortality and demonstrates the feasibility and potential benefits of closed removal of the rod in an operating room just before laparotomy. The presence of an intestinal perforation increases the infection risk, but infections can still be prevented in this setting. Shorter time intervals between the incidence and surgery may reduce the infection rate.
\end{abstract}

Keywords: Impalement; iron rod; penetrating spinal injury; rebar; steel rod.

\section{INTRODUCTION}

Steel rod impalements, mostly experienced by construction workers due to falls from heights, are known entities, but only a few patients unfortunately suffer spinal cord injury $(\mathrm{SCl})$. The management of these injuries is challenging due to the lack of guidelines, various clinical presentations resulting from different trajectories, and high risk of infection. They are mostly "once-in-a-lifetime" cases even for the reasonably experienced trauma surgeons. In addition to their rarity, not knowing the management strategy beforehand is one of the major obstacles in achieving successful treatment outcomes in these emergent situations.

The actual incidence of spinal trauma due to steel rod impalement has not been reported. "Other penetrating wounds: stabbing, impalement, etc." accounts for only $0.3 \%$ of all SCls, and steel rod impalements constitute only a part of these according to the National Spinal Cord Injury Database. ${ }^{[1]}$

Cite this article as: Sarıca C, Yücetaş ŞC, Üçler N, Ballı S, Turgut K, Topçu Sarıca L, et al. Steel rod impalement injuries involving the spine: A case report and literature review. Ulus Travma Acil Cerrahi Derg 2019;25:417-423.

Address for correspondence: Can Sarıca, M.D.

Adıyaman Üniversitesi Tıp Fakültesi, Beyin ve Sinir Cerrahisi Anabilim Dalı, Adıyaman, Turkey

Tel: +90 416 - 2231690 E-mail: can.sarica@gmail.com

Ulus Travma Acil Cerrahi Derg 2019;25(4):417-423 DOI: 10.5505/tjtes.2018.83727 Submitted: 01.08.2018 Accepted: 29.10.2018 Online: 08.07.2019

Copyright 2019 Turkish Association of Trauma and Emergency Surgery 
Here, we present the case of a concrete reinforcing steel rod penetrating through the perineum into the $L 4$ vertebral body, which was successfully managed using a multidisciplinary approach, with planned diagnostic workup and sequenced surgical procedures. We further discuss the management strategies with a review of previous case reports owing to the lack of guidelines for this rare condition.

\section{CASE REPORT}

A 37-year-old male construction worker was admitted to our emergency department due to falling from the second floor onto a concrete reinforcing steel rod approximately $20 \mathrm{~min}$ before admission. On inspection, it was apparent that a steel rod had penetrated the skin through the perineum (Fig. I). He was conscious with a respiratory rate of 17 breaths/min, blood pressure of $136 / 92 \mathrm{mmHg}$, and heart rate of $96 \mathrm{bpm}$. There was no active external bleeding. His medical history was not significant, and physical examination was normal, except for paralysis of the dorsal and plantar flexor muscles and numbness of the left foot.

Multiplanar computed tomography (CT) of the lumbar spine revealed a foreign body penetrating through the perineum to the left posterosuperior margin of the L4 vertebral body (Fig. $2 a-d)$. The patient was transferred to the operating room following the administration of tetanus for prophylaxis and empirical antibiotics (vancomycin I g intravenous (iv) by slow infusion over I h + meropenem $2 \mathrm{~g}$ iv). In addition to the neurosurgeons, general and cardiovascular surgeons were also included in the operating team.

The rod was loose and was gently pulled out externally before the surgery in the operating room under general anesthesia. Skin laceration was sutured, and the patient was placed in the supine position for laparotomy, which was performed via median umbilical incision by a general surgeon. There was no major vascular injury, but there was an approximately $\mathrm{I} \mathrm{cm}$ laceration on the anterior surface of the rec-

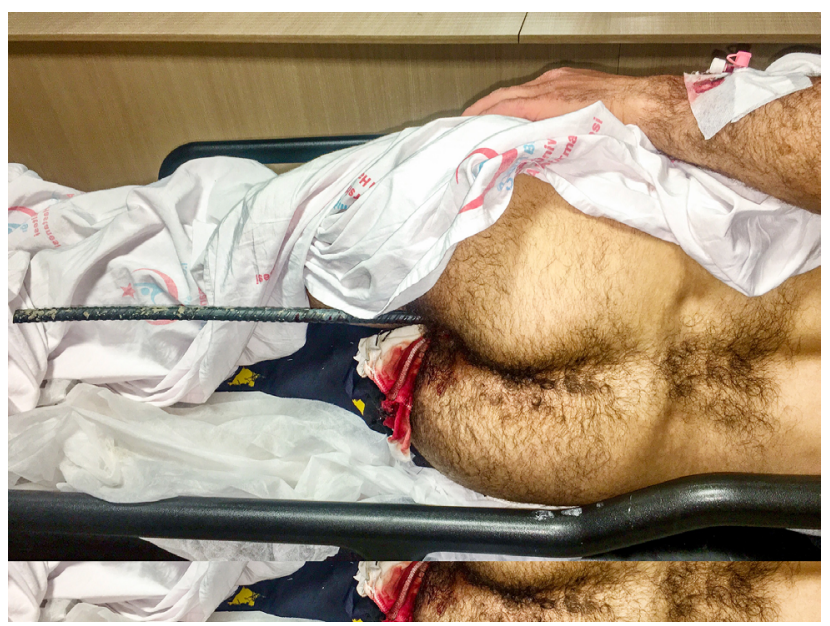

Figure 1. The patient was impaled with a steel bar through his perineum. tum. The rod damaged the sigmoid mesocolon and entered the spine through the anterior surface of the SI vertebral body. Rectal laceration was primarily repaired, and colostomy was performed from the sigmoid colon to the abdominal wall. The patient was transferred to the intensive care unit post-surgery with a neurological examination finding similar to the preoperative state. New lumbar CT and lumbar magnetic resonance imaging (MRI) were ordered (Fig. 3a-d). The patient was again operated to remove the intracanalicular bony fragments $14 \mathrm{~h}$ after the incidence. He was placed in the prone position, and L5 laminectomy was performed. The bony fragments were ablated using an ultrasonic bone shaver (BoneScalpel; Misonix, NY, USA). On exploration, the anterior surface of the dura at the L4 and L5 vertebral levels was observed to have been lacerated longitudinally on the left side, and the cauda equina roots were also damaged at this level. A tissue sealant (Tisseel; Baxter, CA, USA) was used for repair, and an autogenic fat graft on the lesion was placed to prevent cerebrospinal fluid (CSF) leakage. The spine was stabilized by a transpedicular screw system (Fig. 4a-b). There was no significant motor function change after the surgery. On postoperative day 2, the urinary catheter was removed, and the patient did not report any urinary problems thereafter. His anal sphincter tonus was normal and could be constricted voluntarily. No sign of infection was seen on clinical and laboratory examinations; therefore, antibiotic treatment (vancomycin + meropenem) was terminated on day 14 after
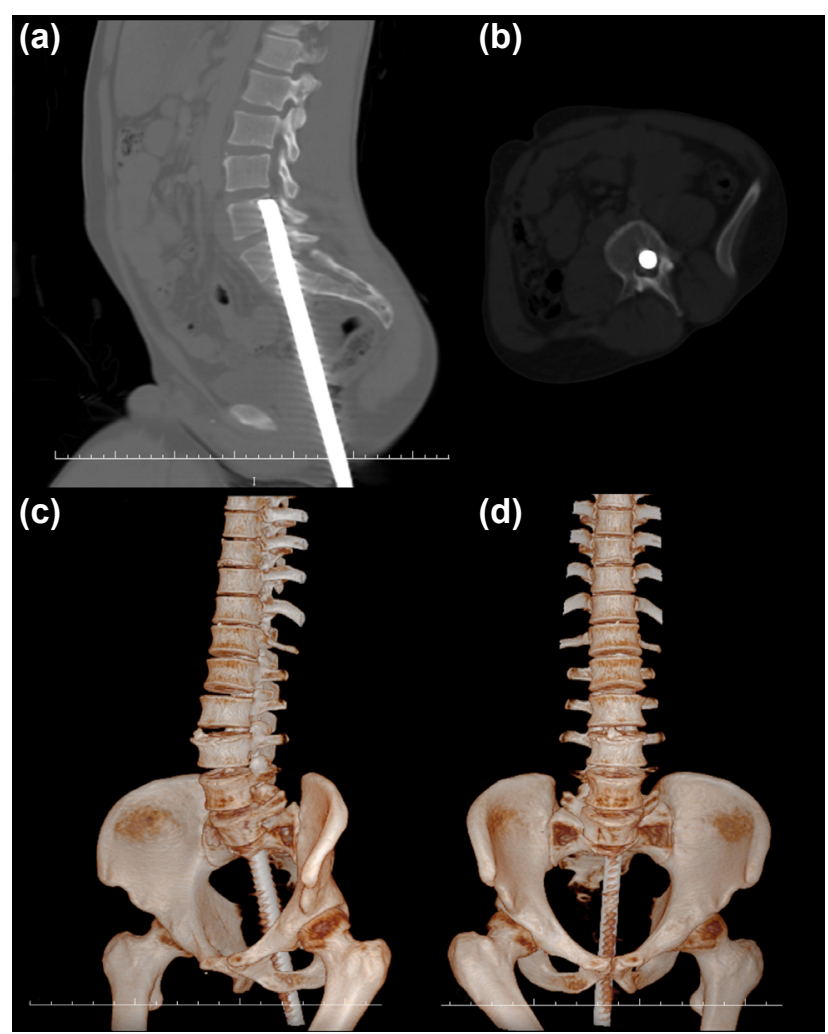

Figure 2. Sagittal (a), axial (b), and three-dimensional (c, d) views of the preoperative noncontrast CTs showing a foreign body (steel rod) penetrating through the perineum to the left posterosuperior margin of the L4 vertebral body. 

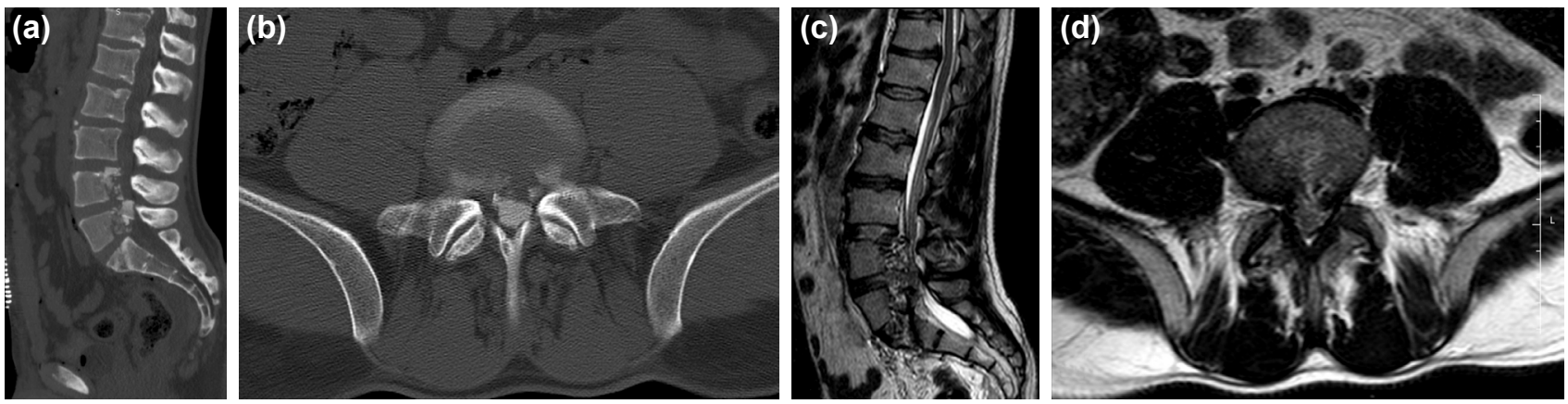

Figure 3. Sagittal (a) and axial (b) views of the post-laparotomy noncontrast CTs revealing bony fragments in the spinal canal. Sagittal (c) and axial (d) views of the post-laparotomy MRI revealing the association between cauda equina roots and bony fragments in the spinal canal.
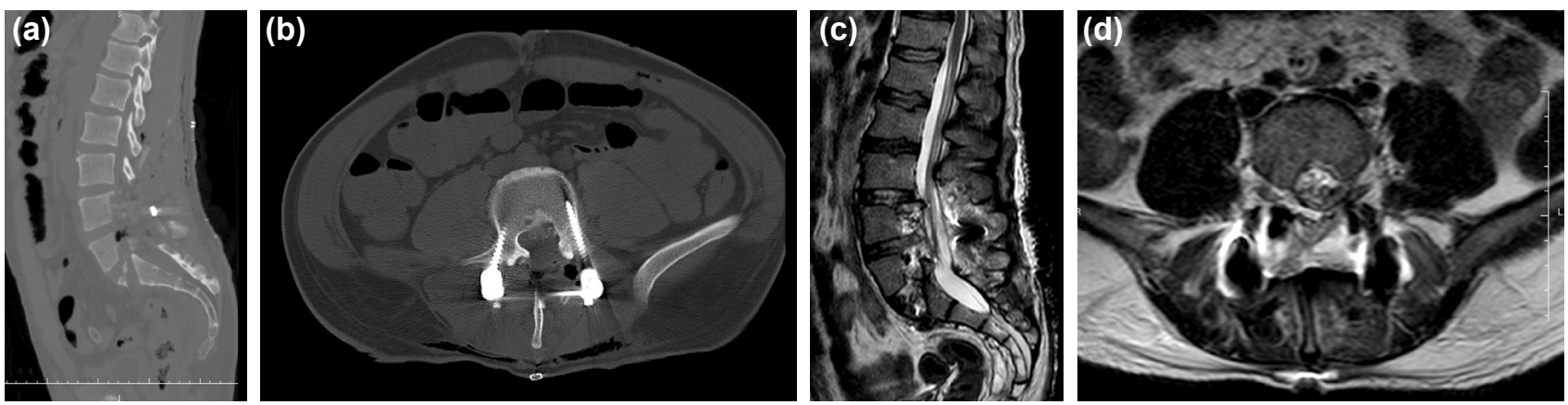

Figure 4. Sagittal (a) and axial (b) views of the post-laminectomy noncontrast CTs revealing the removal of the bony fragments from the spinal canal. Sagittal (c) and axial (d) views of the post-laminectomy MRI revealing the decompression of the cauda equina roots.

the incidence. The patient was discharged with paralysis of the dorsal and plantar flexor muscles of the left foot. At 3 months following the injury, he was ambulatory using an armrest based on the same motor examination as that performed on presentation, with no bowel and urinary incontinence.

\section{DISCUSSION}

Eight case reports involving nine patients with steel rod impalement injuries involving the spine were identified in an extensive review of the English literature on PubMed (Table I). We concluded that steel rod impalement injuries sparing the spine are not extremely rare, with different entrance sites, such as the oral cavity, ${ }^{[2]}$ orbita, ${ }^{[3]}$ nose, ${ }^{[4]}$ cranium, ${ }^{[5]}$ neck, ${ }^{[6]}$ thorax, ${ }^{[7]}$ abdomen, ${ }^{[8]}$ hand, ${ }^{[9]}$ rectum, ${ }^{[10]}$ buttock, ${ }^{[1]}$ and groin. [12] Most victims of steel rod impalement injuries are construction workers, and we believe that occupational safety specialists have to focus on this type of injury to decrease the incidence of this mostly preventable condition. No specific management guideline is currently available owing to the rarity of this injury type. Thus, we aimed to discuss the current management strategies, particularly the controversial ones, in a step-by-step approach.

\section{Management in the Emergency Department and Radiographic Studies}

A patient suspected with a steel rod impalement injury involving the spine must undergo complete trauma assessment upon arrival to rule out any serious-associated injuries. ${ }^{[13]}$
After ensuring a patent airway and hemodynamic stability, radiographic studies must be performed to determine the trajectory of the rod, which is most likely embedded in the bony spine, as seen in the reviewed case reports. In case of trauma parallel to the axis of the spine, the hardness of the bony spine largely reduces the penetrating energy of the rod, thereby blocking its passage. However, perpendicular or oblique injuries may cross the bony spine. Only $3(30 \%)$ of the 10 patients in our review experienced such trauma, and the rod's penetrating end exited the body only in one pediatric patient. ${ }^{[14]}$

Multiplanar CT is ideal for assessing the trajectory of the rod, its associations with the viscera and major vessels, degree of spine involvement, bone fragments in the spinal canal, and hematomas, if any. CT angiography (CTA) may help to determine the vascular associations in case any vascular injury is suspected. Digital subtraction angiography can be an alternative to CTA. In our case, the conventional plain X-ray imaging was not used to save time, because it does not provide additional information to $\mathrm{CT}$ in this condition. However, it may be useful in cases in which there is difficulty in positioning the patient for CT due to the unavailability of rod scissors. Since rods are mostly ferromagnetic, MRI may cause heating or movement of the rod, which may exacerbate the neurological injury. 18-Fluorodeoxyglucose positron emission tomography/CT does not play any role in the initial management, but it can be useful in identifying spinal infection, which is likely after such injuries. ${ }^{[15]}$ 


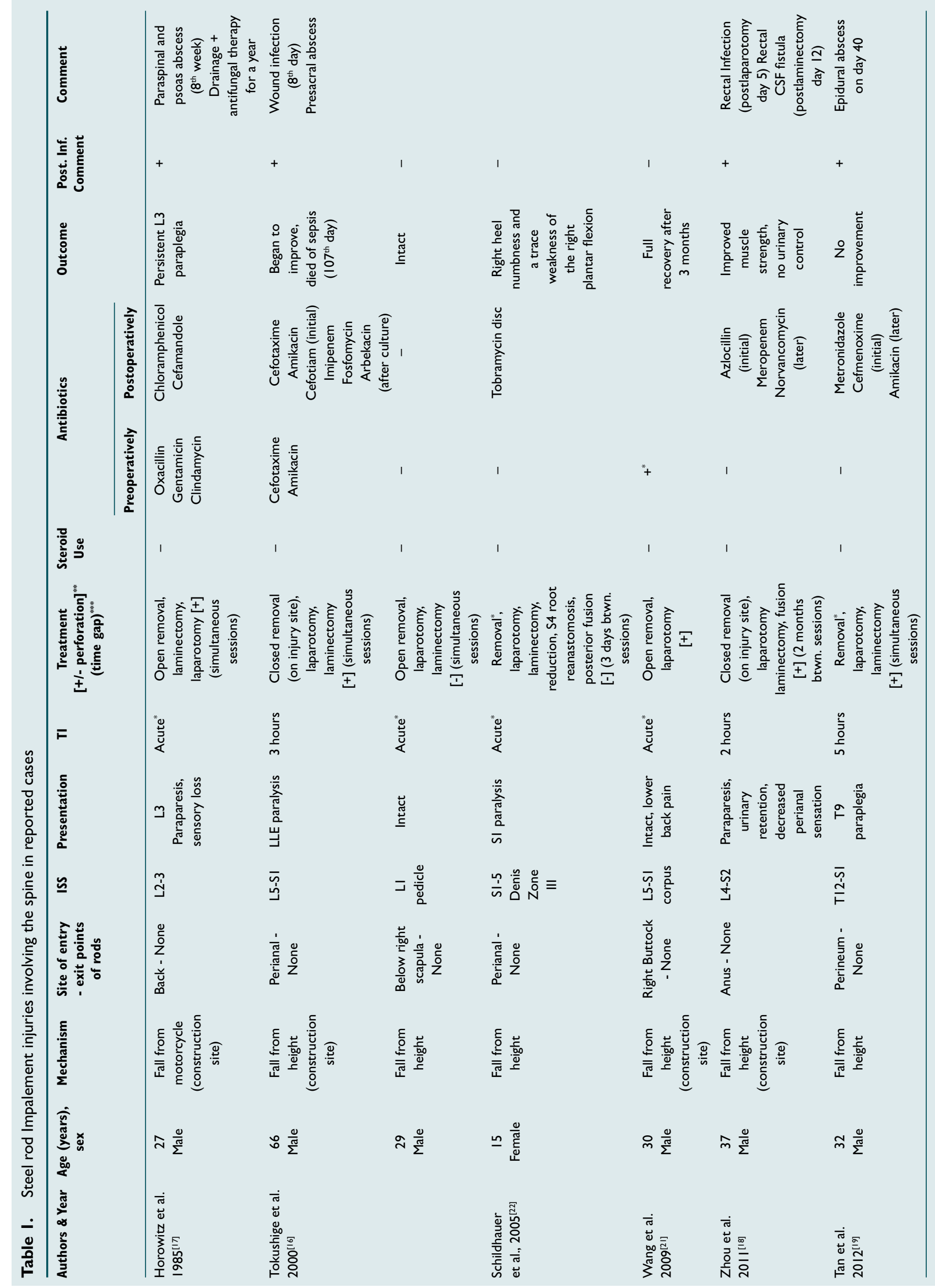




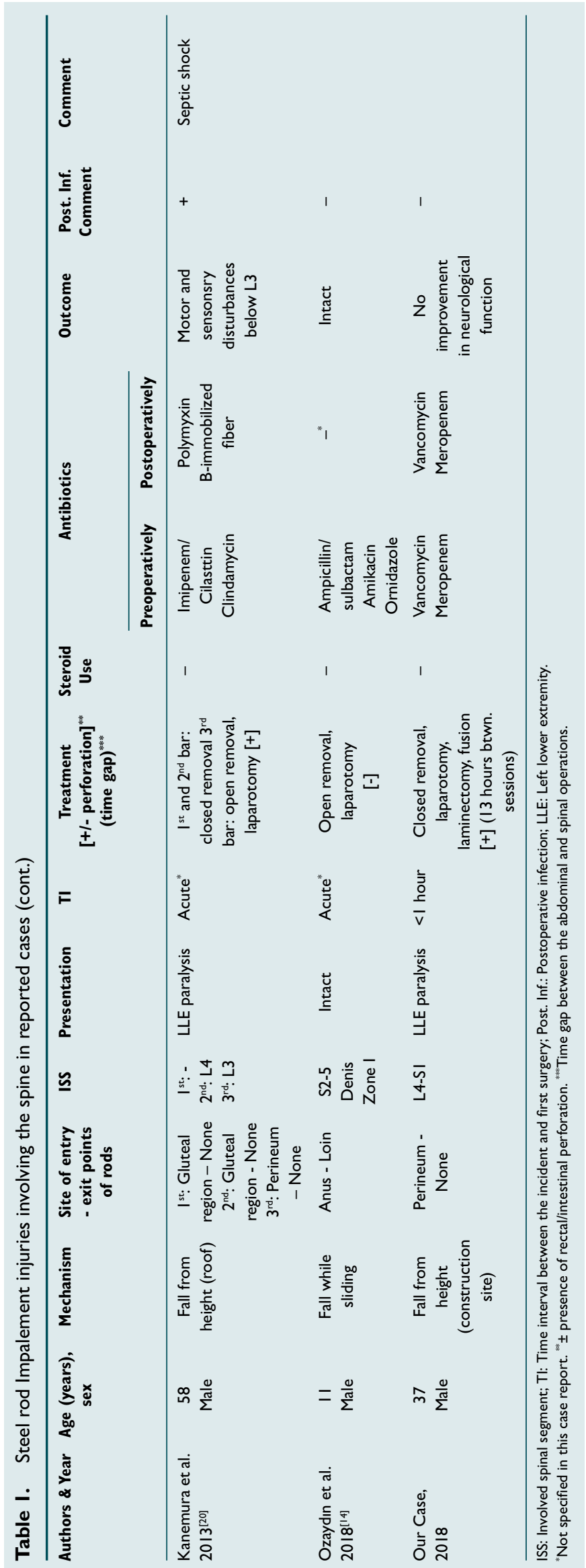

Infection Prophylaxis, Embedded Foreign Body Removal, and Steroid Administration Infection is a major concern in this type of injury; it may even result in mortality as in the case presented by Tokushige et al. ${ }^{[16]}$ Five (50\%) patients in our review experienced infection after the initial surgery, and all the infected patients (100\%) had intestinal (mostly rectal; 80\%) perforations. ${ }^{[16-20]}$ However, intestinal perforations do not always lead to infection, similar to our case or by Wang et al. ${ }^{[21]}$ Three (30\%) patients without any associated intestinal perforations did not experience any infection. ${ }^{[14,16,22]}$

The time interval between the incidence and initial surgery was particularly reported in only four cases. Three of these patients with intervals of 2, 3, and $5 \mathrm{~h}$ developed an infection, but our patient who had an interval of $<$ I h did not. ${ }^{[16,18,19]}$ Unfortunately, the use of statistical analyses was not suitable in this review to establish an association between the time interval and infection rates because of the small sample size. However, we hypothesized that shorter time intervals result in lower infection rates based on existing data.

Another factor that may affect the infection rate is the time interval between laparotomy and laminectomy. Three $(\mathbf{7 5} \%)$ of the four patients who had simultaneous sessions of laparotomy and laminectomy developed postoperative infection, whereas two patients who had 13-hour and 3-day long intervals, respectively, between laparotomy and laminectomy did not. One patient developed an infection after laparotomy and was under antibiotic therapy for 2 months before laminectomy (Table I).

Tokushige et al. ${ }^{[16]}$ advocated that if the rod first penetrates the intestine, and then the spine, it would result in an increased infection rate. Only two cases have been reported in the literature wherein the rod first penetrated the spine and then the intestine; one had a postoperative infection, ${ }^{[17]}$ and the other showed full recovery without any infection. ${ }^{[16]}$ Therefore, it was not possible to verify this hypothesis.

In light of this evidence, the use of broad-spectrum antibiotics and tetanus prophylaxis on admission and in the postoperative period was recommended, similar to that reported in other studies, ${ }^{[23]}$ particularly in the setting of intestinal perforation. The time interval between the incidence and surgery and laparotomy and laminectomy and order of spinal and intestinal penetration of the rod may affect the infection rates; however, further studies using larger case series are needed to verify these speculations.

To the best of our knowledge, no patient in the literature received high-dose steroid therapy for this injury type. 
Our patient did not receive any steroids, because their effectiveness in $\mathrm{SCl}$ remains controversial. ${ }^{[24]}$ However, their use is weakly suggested in $\mathrm{SCl}$ as an option by a recent guideline. [25] Furthermore, the effects of steroids on the infection rate are also controversial with studies denoting both increase ${ }^{[26]}$ and decreased ${ }^{[27]}$ rates.

As stated in previous case reports, the embedded iron rod should not be removed at the incidence site or in the hospital by paramedics or emergency staff prior to the surgery, because it may create laceration in a major vessel wall, possibly causing major bleeding. ${ }^{[13,16,17]}$ In addition, the removal of the rod at the incidence site may increase the infection rate. Two patients whose embedded rods were removed at the incidence site developed serious infections. ${ }^{[16,18]}$ On the other hand, closed removal prior to the surgery in the operation room setting under the guidance of a general or cardiovascular surgeon may be beneficial, as seen in our case. One certain benefit of this approach is patient positioning. The patient can be easily placed in the supine position following closed removal of the rod, thereby making it easy to perform laparotomy. However, whether closed removal affects the infection rates remains unclear. The removal of the rod before the surgery helped us prepare the surgical site more effectively and interrupt the connection of the external environment with the body during the surgery. Touching the unsterile rod during open removal using sterile instruments may spread the microorganisms present on the rod to uncontaminated sites. However, it is mandatory to evaluate the trajectory of the rod and its association with the major vessels to avoid major bleeding by unplugging a lacerated vessel for a closed removal. Having a cardiovascular surgeon in the team during closed removal is logical, given the risk of an unexpected bleeding. Our case is a good example of closed removal of the rod; however, this condition may not be applicable in all cases, and careful preoperative evaluation of the patient is mandatory for decision-making.

\section{Spinal Canal Decompression}

In our case, only a portion of the cauda equina roots at the affected level and side were damaged as a consequence of physical forces of the initial traumatic event. Unfortunately, the affected roots were completely damaged, possibly irreversibly, with the current management strategies. However, it is well-documented that undamaged or partially damaged roots may experience a cascade of secondary injury events (ischemia and expanded zone of neural tissue injury), which may result in newly developed neurological deficits. ${ }^{[28]}$ The American Association of Neurological Surgeons and Congress of Neurological Surgeons guidelines recommend that surgical decompression within $24 \mathrm{~h}$ after $\mathrm{SCl}$ can be performed safely and is associated with an improved neurological outcome. ${ }^{[28]}$ Therefore, laminectomy was performed, and the bony fragments were removed to minimize secondary damage and delayed complications. This delayed-onset injury may even occur years after the first impact, with the formation of reactive bone and soft tissue, thus increasing further compression. [29] Surgical exploration has the advantage of identifying and repairing dural tears and may prevent the formation of CSF fistulas, pseudomeningoceles, and intradural infections.

\section{Conclusion}

We believe that our case demonstrates a good example of careful preoperative planning, multidisciplinary approach, and appropriately sequenced interventions, resulting in an acceptable outcome in this injury type with high morbidity and mortality. It exceptionally demonstrated the feasibility and potential benefits of closed removal of the rod in the operating room just before laparotomy in selected patients. The presence of intestinal perforation increases the infection risk, but infections can still be prevented in this setting. Shorter time interval between the incidence and surgery may decrease the infection rates.

\section{Acknowledgments}

This article is partly supported by the Turkish Neurosurgical Society.

\section{Funding}

The authors have not declared a specific grant for this research from any funding agencies in the public, commercial, or not-for-profit sectors.

\section{Conflict of interest: None declared.}

\section{REFERENCES}

1. Chen Y, Tang Y, Vogel LC, Devivo MJ. Causes of spinal cord injury. Top Spinal Cord Inj Rehabil 2013;19:1-8. [CrossRef]

2. Lan ZG, Richard SA, Li J, Yang C. Nonprojectile penetrating iron rod from the oral cavity to the posterior cranial fossa: a case report and review of literature. Int Med Case Rep J 2018;11:41-5. [CrossRef]

3. Agrawal A, Reddy VU, Kumar SS, Hegde KV, Rao GM. Transorbital Orbitocranial Penetrating Injury with an Iron Rod. Craniomaxillofac Trauma Reconstr 2016;9:145-8. [CrossRef]

4. Yousefi J, Mobasher Jannat A, Ajudani R. Penetrating nose and maxillary sinus injury with a metal part of a military gun. J R Army Med Corps 2016;162:137-8. [CrossRef]

5. Sonmez E, Borcek AO, Guven C, Hasturk AE. An iron rod stuck in the right motor cortex. Turk Neurosurg 2012;22:772-4. [CrossRef]

6. Rautji R, Behera C, Dogra TD. An unusual fatal construction site injury in India: a case report. Med Sci Law 2009;49:222-3. [CrossRef]

7. Liu YW, Tsai DL, Chou SH, Chen CW. Video-Assisted Thoracoscopic Surgery for Thoracic Impalement With an Iron Rod. Ann Thorac Surg 2017;104:1438-9. [CrossRef]

8. Kaur K, Singhal SK, Bhardwaj M, Kumar P. Penetrating abdomino-thoracic injury with an iron rod: An anaesthetic challenge. Indian J Anaesth 2014;58:742-5. [CrossRef]

9. El Alwany AM. Wrist watch causing impalement of the hand by a thick steel rod. J Hand Surg Eur Vol 2010;35:684. [CrossRef]

10. Amarjothi JM, Williams R, Inpharasun SA. Impalement injury with transanal prolapse of bowel content due to intraperitoneal rectal tear. Indian J Surg 2015;77:72. [CrossRef]

11. Lee SH, Park SY, Kim J, Huh YJ. Piercing injury of the pelvis with a steel 
bar. Orthopedics 2012;35:88-90. [CrossRef]

12. Khandelwal A, Singh GP, Kharwar RK, Deganwa M. An iron rod restricting access to airway: an unusual presentation. Anaesthesiol Intensive Ther 2017;49:241-2. [CrossRef]

13. Shahlaie K, Chang DJ, Anderson JT. Nonmissile penetrating spinal injury. Case report and review of the literature. J Neurosurg Spine 2006;4:400-8. [CrossRef]

14. Ozaydin S, Gulleroglu A, Karaaslan B, Celebi S, Besik C, Toker MK, et al. Penetrating injury caused by a long iron bar: A case report. North Clin Istanb 2018;5:75-8. [CrossRef]

15. Kim SJ, Kim IJ, Suh KT, Kim YK, Lee JS. Prediction of residual disease of spine infection using F-18 FDG PET/CT. Spine (Phila Pa 1976) 2009;34:2424-30. [CrossRef]

16. Tokushige J, Inokuchi A, Kawaguchi H. Impalement injuries involving the spinal canal. J Orthop Sci 2000;5:614-7. [CrossRef]

17. Horowitz MD, Dove DB, Eismont FJ, Green BA. Impalement injuries. J Trauma 1985;25:914-6. [CrossRef]

18. Zhou Z, Song Y, Cai Q, Li T, Liu H. Penetrating injury of rectum and vertebral body by steel bar causing cauda equina syndrome. Spine (Phila Pa 1976) 2011;36:803-7. [CrossRef]

19. Tan H, Guo QS, Zhang LY, Sun SJ, Yao YZ, Huang XY. Abscess formation in vertebral canal and presacral area following penetrating injury of rectum and sacral vertebra by a steel rod. Chin J Traumatol 2012;15:241-3.

20. Kanemura T, Hifumi T, Okada I, Kiriu N, Ogasawara T, Hasegawa E, et al. Management of a gluteal region impalement injury caused by three reinforced aluminum bars: a case report. J Med Case Rep 2013;7:295.

21. Wang LT, Wu CC, Hsiao CW, Feng CC, Chang CF, Jao SW. Steel bar penetrating injury of rectum and vertebral body without severe morbidities: report of a case. Dis Colon Rectum 2009;52:346-8. [CrossRef]

22. Schildhauer TA, Chapman JR, Mayo KA. Multisegmental open sacral fracture due to impalement: a case report. J Orthop Trauma 2005;19:134-9. [CrossRef]

23. Heary RF, Vaccaro AR, Mesa JJ, Balderston RA. Thoracolumbar infections in penetrating injuries to the spine. Orthop Clin North Am 1996;27:69-81.

24. Bydon M, Lin J, Macki M, Gokaslan ZL, Bydon A. The current role of steroids in acute spinal cord injury. World Neurosurg 2014;82:848-54.

25. Fehlings MG, Wilson JR, Tetreault LA, Aarabi B, Anderson P, Arnold PM, et al. A Clinical Practice Guideline for the Management of Patients With Acute Spinal Cord Injury: Recommendations on the Use of Methylprednisolone Sodium Succinate. Global Spine J 2017;7:203S-11S.

26. Ito Y, Sugimoto Y, Tomioka M, Kai N, Tanaka M. Does high dose methylprednisolone sodium succinate really improve neurological status in patient with acute cervical cord injury?: a prospective study about neurological recovery and early complications. Spine (Phila Pa 1976) 2009;34:2121-4. [CrossRef]

27. Cage JM, Knox JB, Wimberly RL, Shaha S, Jo C, Riccio AI. Complications Associated With High-dose Corticosteroid Administration in Children With Spinal Cord Injury. J Pediatr Orthop 2015;35:687-92.

28. Ahuja CS, Nori S, Tetreault L, Wilson J, Kwon B, Harrop J, et al. Traumatic Spinal Cord Injury-Repair and Regeneration. Neurosurgery 2017;80:S9-S22. [CrossRef]

29. Conway JE, Crofford TW, Terry AF, Protzman RR. Cauda equina syndrome occurring nine years after a gunshot injury to the spine. A case report. J Bone Joint Surg Am 1993;75:760-3. [CrossRef]

\section{OLGU SUNUMU - ÖZET}

\section{Omurgaya saplanan çelik çubuk: Olgu sunumu ve literatür taraması \\ Dr. Can Sarıca, ${ }^{1}$ Dr. Şeyho Cem Yücetaş, ${ }^{1}$ Dr. Necati Üçler, ${ }^{1}$ Dr. Sadi Ballı, ${ }^{2}$ Dr. Kasım Turgut, ${ }^{3}$ Dr. Leyla Topçu Sarıca, ${ }^{4}$ Dr. Süleyman Kııınç ${ }^{1}$}

${ }^{1}$ Adıyaman Üniversitesi Tıp Fakültesi, Beyin ve Sinir Cerrahisi Anabilim Dalı, Adıyaman

${ }^{2}$ Adıyaman Üniversitesi Tıp Fakültesi, Genel Cerrahi Anabilim Dalı, Adıyaman

${ }^{3}$ Adıyaman Üniversitesi Tıp Fakültesi, Acil Tıp Anabilim Dalı, Adıyaman

${ }^{4}$ Adıyaman Üniversitesi Tıp Fakültesi, Anestezioloji ve Reanimasyon Anabilim Dalı, Adıyaman

Yüksekten düşme sonrasında özellikle inşaat işçilerinin etkilendikleri çelik çubuk saplanması bilinen bir travma türüdür, fakat sadece çok az sayıda şanssız kişi bu tarz bir travma sonrasında spinal kord hasarı ile karşımıza gelmektedir. Yüksek enfeksiyon riski, farklı güzergahlara bağı çok fazla varyasyon gösteren klinik tablolar ve ilgili herhangi bir mevcut kılavuzun bulunmaması bu tarz travmalarını başarılı yönetimini zorlaştırmaktadır. Bu yazıdaki amacımız, nadir görülen spinal kord hasarına neden olan çelik çubuk saplanması olan bir hasta sunmak, ilgili literatürleri tarayarak bu travmanın yönetimini geliştirmek ve enfeksiyon başta olmak üzere komplikasyonlara neden olan risk faktörlerini belirlemektir. Otuz yedi yaşında erkek inşaat iş̧̧isi çalışırken yüksekten düşme sonrası perinesinden girip L4 omurga gövdesine saplanan çelik çubuk nedeniyle başvurdu. Muayenesinde sol ayakta motor ve duyu kaybı mevcuttu. Çelik çubuk genel anestezi altında operasyon odasında çekildi ve sonrasında laparotomi ile rektal laserasyon primer onarılıp kolostomi açıldı. Farklı bir oturumda laminektomi yapıldı. Hastanın taburcu olduktan üç ay sonraki muayenesi gelişi ile aynıydı ve hasta koltuk değnekleri ile yürüyebiliyordu. Bu olgu, dikkatli bir ameliyat öncesi planlama, multidisipliner yaklaşım ve farklı sekanslı planlanan girişimler ile kabul edilebilir bir klinik sonuç elde edilmesi açısından örnek teşkil etmektedir. Laparatomi öncesi kapalı olarak çubuğun çıkartılabileceğinin uygunluğunu ve olası yararlarını ortaya koymaktadır. Bağırsak perforasyonu enfeksiyon riskini artırmaktadır fakat bu durumda bile enfeksiyon önlenebilir. Olay ve cerrahi arasındaki sürenin kısa olması enfeksiyon ihtimalini azaltabilir.

Anahtar sözcükler: Çelik çubuk; enfeksiyon; penetran omurga yaralanması; saplanma.

Ulus Travma Acil Cerrahi Derg 2019;25(4):417-423 doi: 10.5505/tjtes.2018.83727 